\title{
The Research of Heavy Metals Stabilization in the Municipal Solid Waste Incineration Fly Ash Using Silica Nanocomposites
}

\author{
Zamira KAZIZOVA ${ }^{1 *}$, Saulius VASAREVIČIUS ${ }^{2}$, Dace LAUKA ${ }^{3}$ \\ ${ }^{1,2}$ Vilnius Gediminas Technical University, Sauletekio al. 11, Vilnius, LT-10223, Lithuania \\ ${ }^{3}$ Riga Technical University, Azenes iela12/1, Riga, LV-1048, Latvia
}

\begin{abstract}
Municipal solid waste has become a serious problem because of rapid urbanization and great economic growth. As a result of these, huge impacts on the environment lead to a lot of problems not only air, soil or water pollution but human health too. One of the solutions to manage MSW problem is incineration with energy recovery that can reduce a large amount of waste in volume. But the activity of incineration plant is associated with the formation of a large amount of hazardous waste, a significant part is fly ash which is by-products of MSW contains a high number of heavy metals and salts which are very toxic. Fly ash is a really topical question today and it is important to find out how to dispose of it properly due to hazardous contents. In this study was performed the municipal solid incineration fly ash evaluation, experimental research of heavy metal composition of seven types of a concrete mixture containing different amounts of MSWI fly ash, silica nanocomposites for the determination of the best alternative and employing a SWOT analysis.
\end{abstract}

Keywords - Concrete; hazardous waste; leaching; waste management

\section{INTRODUCTION}

Currently, solid waste management has become a global problem due to growing cities and countries with economies in transition. This subsequently leads to increased public concern about the consequences for human and environmental health. Thus, waste management strategies should be directed towards preventing waste generation and cutting its harmfulness. A well-known practice to waste management materials should be reused, recycled or recovered, or the conversion of waste into energy. In a decisive way, waste should be safely disposed of generally in ways as landfill or incineration.

However, a sanitary landfill is an alternative solution for waste that has no other destination, unfortunately it has many disadvantages: maintaining a designed sanitary landfill is costly and a dead end for all the valuable resources it contains. Secondly, landfills require land and the consequent potential for contamination, for example, contamination of groundwater due to leaching and emissions of landfill gases like methane, which has a global warming potential and makes it the less satisfactory way to remove waste. In response, the European Union issued a directive in 1999 with the aim of prohibiting the disposal of all waste, except hazardous waste. Countries like the United States and New Zealand have imposed a landfill

* Corresponding author.

E-mail address: zamira.kazizova@gmail.com 
tax to avoid the disposal of recyclable resources. In addition, circular economy action plans are one of the main policies that focus on minimizing landfills [1].

Therefore, incineration is an effective approach to energy recovery and reduces the amount of waste by more than $90 \%$ [2]. The incineration process includes three main parts: incineration, energy recovery, and air pollution control. Nowadays, air pollution is part of the biggest problems for incineration. However, modern incinerators and innovative pollution control system are developed to minimize pollution and provide compliance with environmental standards. A dry or wet scrubber is used to spray fine particulate matter into hot exhaust gas to neutralize the acidic gases as sulphur oxides and hydrogen chloride. An activated carbon column or injected sprayed activated carbon is used to adsorb heavy metal and organic pollutants such as Printed circuit board (PCB) and Volatile organic compounds (VOC) in the exhaust gas [2].

Hence, the system of selective non-catalytic reduction is utilized to remove nitrogen oxides by adding urea or ammonia for reaction to nitrogen, carbon dioxide and water. The bag filter system is intended to filter and remove small particles and dust particles as well [2].

\subsection{Fly Ash: Properties, Composition and Hazard}

Fly ash is waste material generated as a by-product of coal or a municipal solid waste of incineration. Notably, waste has a huge influence on its properties, thereby it is important to know that waste has a great impact via the physical and chemical properties of fly ash. Usually it depends on the content of the raw MSW, combustion conditions, the type of incinerator, air pollution control devices, processing methods, and a certain type of waste [3]. Consideration in terms of the chemical side includes such parameters as corrosive, toxicity, reactive and ignitability. Therefore, this is relevant for the understanding of waste behaviour as it moves through the waste management system. Secondly, consideration is regarding physical properties which are critical for the selection and operation of equipment and for the analysis and design of disposal sites. Such parameters include specific weight, moisture content, particle size and size distribution, field capacity and compacted waste porosity [4].

The principal property in terms of physical properties of fly ash particles is size, over $80 \%$ have diameters between $0.105 \sim 0.154 \mathrm{~mm}$, and the mass ratios of particles normally smaller than $0.063 \mathrm{~mm}$ and larger than $0.154 \mathrm{~mm}$ are both lower than $5 \%$. Furthermore, the fly ash is regarded as not chemically inert, but containing a high amount of water-leachable toxic heavy metals and their salts including $\mathrm{Cd}, \mathrm{Pb}, \mathrm{Zn}, \mathrm{Cr}$, etc., that make them a type of hazardous waste [5].

Thereby, leaching toxicity of heavy metals in fly ash is the most important indicator for assessing their environmental impact and providing the technical basis for treating and disposing of fly ash, since these hazardous elements influence human and environmental health [3]. The major concerns are elements identified as bio-accumulating in humans and animals which include Arsenic, Lead, Cadmium, Mercury, and Chromium; and in animals Selenium and Copper. Thus, some elements accumulate within the body until toxic concentrations and therefore may cause adverse health effects [6].

There are the main chemical properties such as chemical composition, loss on ignition, heavy metals and leachability, organic constituents. The composition of municipal solid waste can vary after a while depends on differences in countries' lifestyle, waste recycling process accordingly ash content can vary too [2]. The composition of fly ash is a complex in $\mathrm{Si}, \mathrm{Al}$, $\mathrm{Ca}, \mathrm{Mg}, \mathrm{Na}, \mathrm{O}, \mathrm{C}, \mathrm{Cl}$, and $\mathrm{S}$, which mainly existed in $\mathrm{CaCO}_{3}, \mathrm{CaSO}_{4}, \mathrm{NaCl}, \mathrm{KCl}, \mathrm{SiO}_{2}$ and $\mathrm{Ca}_{2} \mathrm{Al}_{2} \mathrm{SiO}_{7}$, where the chemical composition of MSWI fly ash depends on flue gas line. Keppert et al. investigated the effect of the chemical composition of three ashes with different 
separation temperatures higher than $700{ }^{\circ} \mathrm{C}$, between $500{ }^{\circ} \mathrm{C}$ and $700{ }^{\circ} \mathrm{C}$ and the last one between $250{ }^{\circ} \mathrm{C}$ and $300{ }^{\circ} \mathrm{C}$. It was also noted that the content of soluble salts $(\mathrm{Cl}-$ and $\mathrm{SiO} 32-)$ and most heavy metals such as $\mathrm{As}, \mathrm{Cd}, \mathrm{Pb}, \mathrm{Sb}$ increases with reducing separation temperature. Furthermore, heavy metals more cumulative in the fly ash more than bottom ash, except $\mathrm{Cu}, \mathrm{Cr}$, and $\mathrm{Pb}$ because of their low volatility [1].

\subsection{Techniques for Managing Fly Ash Residue}

Recommendations for managing MSW incinerator residues allow disposal or utilization of the bottom ash, fly ash, and combined ash. Special attention to residue management had fly ash thus is considered as hazardous waste that could lead to serious issues. If it is hazardous waste disposal or permanent storage is preferred, thus necessary to take appropriate measures to protect the environment and minimize the contact of the material with water and prevent the uncontrolled release of pollutants into the environment. Utilization of MSWI fly ash residue is a complex process as fly ash considered hazardous waste, therefore, it has to be acknowledged in every aspect. Although there are some techniques that have an alternative and safe solution for managing fly ash from the incineration.

There are four main techniques:

- Separation processes;

- Thermal methods;

- The Carbon-in-Pulp;

- Solidification/Stabilization (S/S).

Usually, it begins from the treatment process with the separation process and followed by $\mathrm{S} / \mathrm{S}$ and then thermal methods. A separation process is inexpensive and environmentally friendly and the main purpose to reduce chloride, salt, alkali, and heavy metals in fly ash and as well as improve the quality of fly ash. But one of the disadvantages of this process is the case that a large number of heavy metals will be released with soluble salts. For better environmental protection, heavy metals in fly ash can be recovered or extracted. The main methods include acid, alkaline, high temperature, or biological extraction, etc [7].

Thermal Methods can be divided into three main categories as vitrification, sintering, and fusion. The first category, vitrification is a chemical process in which a mixture of glass precursors and hazardous waste melts at elevated temperatures to obtain an amorphous singlephase product. The second category, sintering is also a chemical process where a mixture of hazardous waste and small glassy is melted at a high temperature of $1000-1100{ }^{\circ} \mathrm{C}$ to produce a glass waste form. The last category, fusion is a chemical process whereby MSWI fly ash is melted or fused at a really high temperature in the fuel furnace with the formation of either crystalline or heterogeneous products. Currently, this technology admitted as one stable reliable method with such advantages as a high rate of volume reduction and the absence of leaching of heavy metals [7].

The Carbon-in-Pulp takes the form used for the recovery of heavy metals from MSWI fly ash. Fly ash is mixed with $\mathrm{NaCl}$ to leach the metal, and then granular activated carbon serves as an adsorbent for metal adsorption. It was also noted that the process is favourable at low $\mathrm{pH}$ and strongly depends on the concentration of $\mathrm{NaCl}[2]$.

$\mathrm{S} / \mathrm{S}$ method is one of the common methods for now and address of those technologies that use an admixture to immobilize hazardous compositions present in fly ash before landfill disposal. In accordance with "Standard for Pollution Control on the Landfill Site of Municipal Solid Waste", MSWI fly ash going to sanitary landfills after it is preserved and meets the heavy metals leaching toxicity standards [7]. 
- Cement solidification - amongst the various S/S technologies available, cement-based processes are still the most broadly used in hazardous waste treatment because of suitable processing effect, low costs, and ease of use. The United States Environmental Protection Agency (USEPA) has regarded cement hardening technology as the greatest technology for treating hazardous waste. However, the disadvantage of this process is the case that the volume of fly ash will be increased almost doubled in this method [7];

- Chemical stabilization technology can change both the chemical and physical properties of Municipal solid waste incineration fly ash. Existing forms of heavy metals in MSWI fly ash are altered by $\mathrm{pH}$ adjustment, precipitation and adsorption to reduce the bioavailability and mobility of metals and provide stabilization. If to compare with cement solidification that the volume of MSWI fly ash will not change much due to chemical stabilization. There are many types of chemical stabilization for MSWI fly ash which can be separated into two groups: organic and inorganic. Frequently used stabilized agents including gypsum, bleach, sulphides, phosphate, and polymer organic stabilizers [7].

Presently, nanocomposites are showing increasing interest in many industries and have many different applications. Nanocomposites are nearby materials undergoing significant change and are also an economic barrier for developing countries as a tool for nanotechnology [8].

Silica nanocomposites is mostly produced by the fuming method and the precipitation in the industry. Silica is a fine, white, amorphous powder with no odour and taste. It is formed by a high-temperature vapour process in which $\mathrm{SiCl} 4$ is hydrolysed in an oxygen-hydrogen flame according to the reaction:

$$
\mathrm{SiCl}_{4}+2 \mathrm{H}_{2}+\mathrm{O}_{2} \rightarrow \mathrm{SiO}_{2}+4 \mathrm{HCl}
$$

The silica has a large surface and smooth non-porous surface that can contribute strong physical contact between the filler and nanocomposites. To silica-based nanocomposites commonly used fumed silica and rarely used the precipitated one has several groups of silanol $(\mathrm{Si}-\mathrm{OH})$ on the surface and therefore, the agglomerate is much lighter than the fumed one. The primary particle size of silica nanocomposites varies from 4 to $50 \mathrm{~nm}$, average size is $20 \mathrm{~nm}$. Mechanism of incorporation heavy metals and phase conversion in the hydrated MSWI fly ash paste using silica fume as an additive [8].

\section{METHODOLOGY OF EXPERIMENTAL RESEARCH}

The research consisted of large-scale Combined Heat and Power Plant (CHPP) "Fortum Klaipeda" located in the Baltic region of Klaipeda, Lithuania. Municipal Solid Waste Incineration fly ash for this experimental research was sourced from CHPP "Fortum Klaipeda" located in the Baltic region of Klaipeda, Lithuania, which converts municipal and industrial waste, and biomass into heat and electricity. Fly ash refers to solid matter that is formed during the incineration process and collected by heat recovery and flue gas purification systems, where analysis has shown that fly ash consists a large amount of waterleachable toxic heavy metals and salts, including lead, cadmium, zinc, chromium, etc., which makes them a type of hazardous waste [5].

MSWI fly ash was collected from hoppers and stored in a dry condition before testing. The MSWI fly ash samples was taken in UAB "Fortum Klaipeda", Klaipeda, Lithuania. 
TABLE 1. CHEMICAL COMPOSITION OF MSWI FLY ASH “FORTUM KLAIPEDA”.

\begin{tabular}{ll}
\hline Major chemical composition, \% & MSWI fly ash \\
\hline $\mathrm{SiO}_{2}$ & 0.1 \\
$\mathrm{Al}_{2} \mathrm{O}_{3}$ & 1.3 \\
$\mathrm{~K}_{2} \mathrm{O}$ & 3.7 \\
$\mathrm{CaO}$ & 39.8 \\
$\mathrm{MgO}$ & 1.0 \\
$\mathrm{Na} \mathrm{O}_{2} \mathrm{O}$ & 3.1 \\
$\mathrm{Cl}$ & 14.7 \\
\hline $\mathrm{Trace}$ elements contents, $\mathbf{~ m g / k g}$ & MSWI fly ash \\
\hline $\mathrm{Pb}$ & 3380 \\
$\mathrm{Cd}$ & 206 \\
$\mathrm{Cu}$ & 1289 \\
$\mathrm{Cr}$ & 55.1 \\
$\mathrm{Zn}$ & 12131.5 \\
$\mathrm{As}$ & 15.0 \\
$\mathrm{Hg}$ & 10.8 \\
\hline
\end{tabular}

Table 1 shows the major chemical content protocols of MSWI fly ash collected by UAB "Fortum Klaipeda". The major and significant components of MSWI fly ash were $\mathrm{CaO}, \mathrm{K}_{2} \mathrm{O}$, $\mathrm{Al}_{2} \mathrm{O}_{3}, \mathrm{Cl}$ and $\mathrm{SiO}_{2}$, and heavy metals as $\mathrm{Pb}, \mathrm{Cd}, \mathrm{Cu}, \mathrm{Cr}, \mathrm{Zn}, \mathrm{As}$, and $\mathrm{Hg}$.

The research would be done in the following steps:

- Concrete: various concrete mixtures were obtained by partially replacing natural aggregate with stabilized depending on percent correlation. Fly ashes analysed in this work, produced by incineration facility;

- Samples milling: all stabilized waste must grinded with a maximum diameter of $4 \mathrm{~mm}$ because of the reduction of the impact of waste on the concrete;

- Stabilization treatment: by mixing waste with concrete mixture, MSWI fly ash, silica material, and water. Silica material causes the stabilization of fly ash and maintains a $\mathrm{pH}$ to minimize metal leaching.

To produce the mortars, seven different mixtures were prepared. Materials for mortars:

1. The fly ash was taken from UAB "Fortum Klaipeda", Klaipeda, Lithuania. It focuses on Combined Heat and Power Production (CHPP), increasing the efficiency of the central heating system, maintaining long-term competitiveness, and reducing the environmental impact of its production units. CHP plant utilizes non-hazardous municipal and industrial waste as fuel;

2. Silica nanocomposites sample was taken from the Institute of Surface Chemistry, Kyiv, Ukraine. Major chemical composition: $\mathrm{SiO}_{2}, \mathrm{Al}_{2} \mathrm{O}_{3}, \mathrm{Fe}_{2} \mathrm{O}_{3}, \mathrm{CaO}$, etc.

3. The concrete mixture brand which was used in that research is Weber S 100;

4. Water in various volumes depending on the composition of the mixture.

During the experiment, seven types of specimens were made in the laboratory of Vilnius Gediminas Technical University with varying amounts of MSWI fly ash, silica nanocomposites, concrete mixture, and water. 


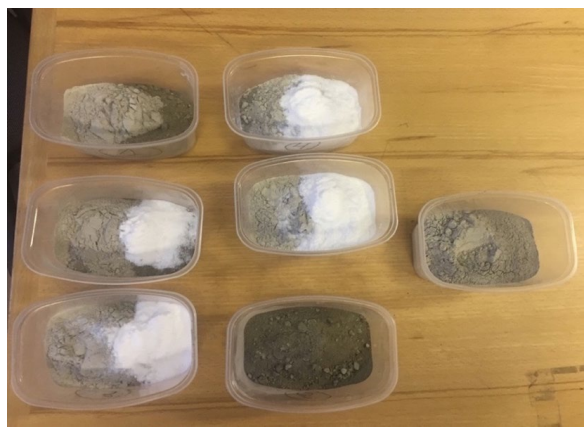

Fig. 1. First steps of mortar preparation.

At first, the necessary quantities of raw materials were weighed and mixed to prepare each specific mixture, and then the mixtures were placed in the forms. Table 2 shows the composition in more detail of every sample.

TABLE 2. MORTAR COMPOSITION IN DIFFERENT DOSAGES

\begin{tabular}{llllllll}
\hline & \multicolumn{2}{l}{ MSWI Fly Ash } & \multicolumn{2}{l}{$\begin{array}{l}\text { Silica } \\
\text { Nanocomposites }\end{array}$} & \multicolumn{2}{c}{ Concrete mixture } & Water \\
\cline { 2 - 7 } & $\mathbf{\%}$ & $\mathbf{g m}$ & $\mathbf{\%}$ & $\mathbf{g m}$ & $\mathbf{\%}$ & $\mathbf{g m}$ & $\mathbf{m l}$ \\
\hline I & 10 & 40 & 0 & 0 & 90 & 360 & 70 \\
II & 9.5 & 38 & 0.5 & 2 & 90 & 360 & 70 \\
III & 9 & 36 & 1 & 4 & 90 & 360 & 80 \\
IV & 8.5 & 34 & 1.5 & 6 & 90 & 360 & 90 \\
V & 8 & 32 & 2 & 8 & 90 & 360 & 95 \\
VI & 0 & 0 & 0 & 0 & 100 & 400 & 50 \\
VII & 90 & 360 & 10 & 40 & 0 & 0 & 190 \\
\hline
\end{tabular}

The next step was adding water to the mixed mortars, where is accordingly specifies that the more FA is added, the more water is needed. After this, the mixing homogeneous mass left for concrete hardening. After one week of hardening samples, we used crushing equipment for the samples. After one stage of crushing, it is following the second stage of crushing where was used equipment called Ball Mill Machine. A ball milling machine is a simple, cost-effective and widely used to grind powders into fine particles and blend materials. Although ball milling is easy to operate and also suitable for polymer or monomeric powders, breakdown of technology can occur in nanotubes. It works on the principle of impact and abrasion: the size is reduced by impact when the balls fall near the top of the shell. For the investigation of the leachate test and measurement of the heavy metal concentration of prepared concrete, the samples particle size should be less than $4 \mathrm{~mm}$.

Testing procedures:

- $1^{\text {st }}$ part - leachate preparation;

- $2^{\text {nd }}$ part - determination of the heavy metal's concentration by electrothermal atomic spectrometric method. 


\section{RESUltS AND ANALYSIS OF EXPERIMENTAL RESEARCH}

To minimize the amount of waste, it is necessary to renew waste and reuse recycled materials as raw materials in various industries while preserving natural resources [9]. CHPP "Fortum Klaipeda" focuses on improving the efficiency of the central heating system, maintaining long-term competitiveness, and minimize the environmental impact of its production units. CHP plant utilizes non-hazardous municipal and industrial waste as fuel.

Accordingly, a high concentration of $\mathrm{CaO}$ takes place due to the excess lime solution forced into the scrubber to deletion acid gases. The high content of $\mathrm{CaO}$ serves to maintain a $\mathrm{pH}$ environment that helps to stabilize some hazardous metals, for instance, $\mathrm{Cu}, \mathrm{Cd}$, etc. In addition, the high content of $\mathrm{Cl}$ is a result of plastics and food wastes and $\mathrm{K}_{2} \mathrm{O}, \mathrm{Na}_{2} \mathrm{O}$ content determines the suitability operations condition of the pollution control system.

Furthermore, previous studies of the composition of MSWI fly ash residues showed that the introduction of more stringent emission limits, the development of improved technologies for controlling air pollution, and incineration of municipal solid waste with a controlled composition led to a decrease in the concentration of various elements in MSWI fly ash [10]. One of the greatest solutions with hazardous content MSWI fly ash is the S/S technique to reduce the long-term dissolution rate of heavy metals in landfills and use the leachability toxicity as a mandatory assessment tool. Therefore, these solidified products can serve as raw materials for cement production or road pavement.

In this research, a new stabilization process proposed and discussed for toxic waste materials. The process comes from the existing process of treating heavy metals in MSWI fly ash from CHPP "Fortum Klaipeda" as silica nanocomposites to produce an inert material that can be used as a filler for many applications, avoiding landfill. One of the advantages of the sustainability of the new process is that no chemicals are involved in the stabilization process, but all reagents are wastes.

The mineral base of the nanocomposite should perform the functions of binding with MSWI fly ash to stabilize heavy metals $(\mathrm{Cd}, \mathrm{Cu}, \mathrm{Pb}, \mathrm{Zn})$ for concrete production.

TABle 3. Determination of HeAvy Metals: CADMium, CopPER, LEAD AND ZinC IN SEVEN SAMPLES

\begin{tabular}{llllll}
\hline Sample & Cd & Cu & Pb & Zn \\
\hline I & Concrete mixture + 10 \% fly ash & $\mathrm{mg} / \mathrm{kg}$ & & & \\
II & Concrete mixture + 9.5 \% fly ash + 0.5 \% silica & 12.7 & 180 & 56 & 1000 \\
III & Concrete mixture + 9 \% fly ash + 1.0 \% silica & 10.9 & 150 & 66 & 980 \\
IV & Concrete mixture + 8.5 \% fly ash + 1.5 \% silica & 10.6 & 140 & 140 & 910 \\
V & Concrete mixture + 8 \% fly ash + 2.0 silica & 9.8 & 120 & 74 & 700 \\
VI & Concrete mixture & $<0.15$ & 16 & 7 & 64 \\
VI & $\mathbf{9 0} \%$ fly ash + 10 \% silica & 95.8 & 1100 & 1600 & 6200 \\
\hline
\end{tabular}

Furthermore, the new proposed methodology was applied for the processing of fly ash from municipal solid waste, which contains a large amount of recoverable $\mathrm{Pb}, \mathrm{Zn}, \mathrm{Cu}$, and $\mathrm{Cd}$. The obtained samples are characterized for understanding the mechanisms of metal work (Table 3). Stabilization includes the initial washing step, during which most of the soluble 
salts and, to some extent, metals are extracted prior to the chemical bonding of the remaining metals. Such methods are completed by dehydration of the stabilized product [11].

The concentration of $\mathrm{Cd}, \mathrm{Cu}, \mathrm{Pb}$, and $\mathrm{Zn}$ were obtained under microwave heating according to EPA Method 200.2 and Method 3050 and after Atomic Absorption Spectrometer Method B (ISO 11466). In this work. these four heavy metals were monitored because of their high quantity in the preliminary leaching solution of MSWI fly ash and also, they are a crucial aspect in MSWI fly ash treatment that directly $\mathrm{pH}$ depend because of excessive alkali content of $\mathrm{CaO}$ in the lime introduced to neutralize the acid gas, the conditions are so strongly basic that it has a major effect on the leaching toxicity of heavy metals.

Cd

(a)

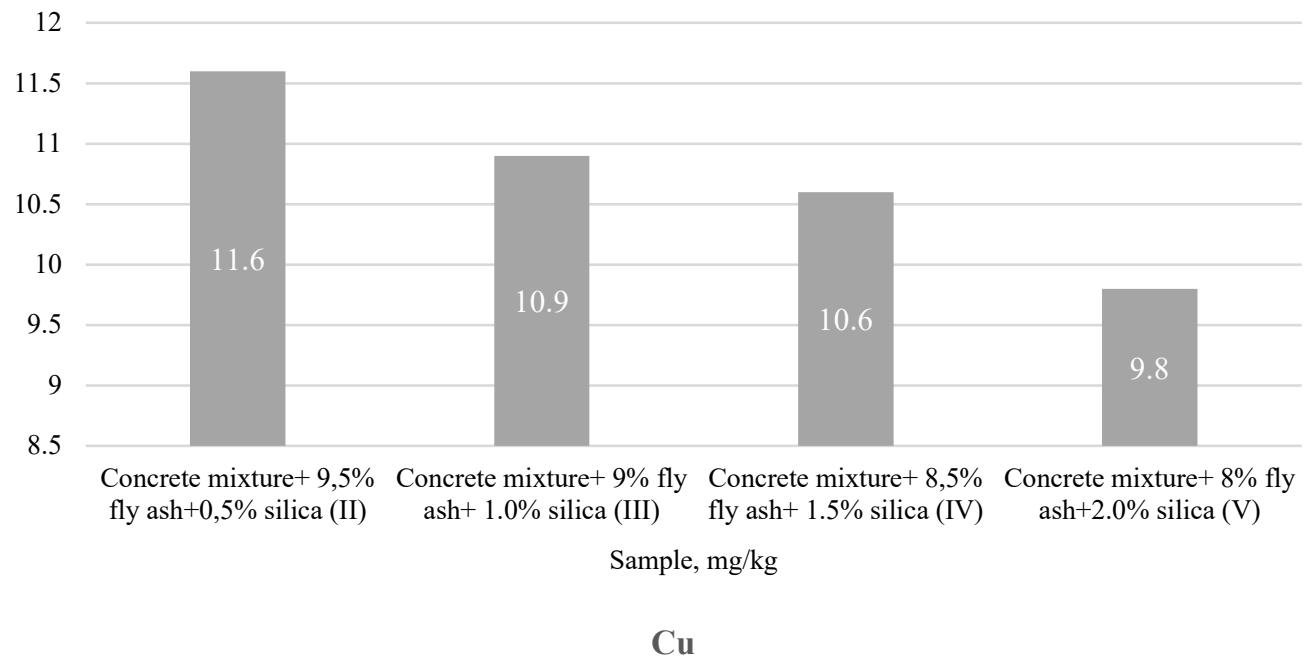

(b)

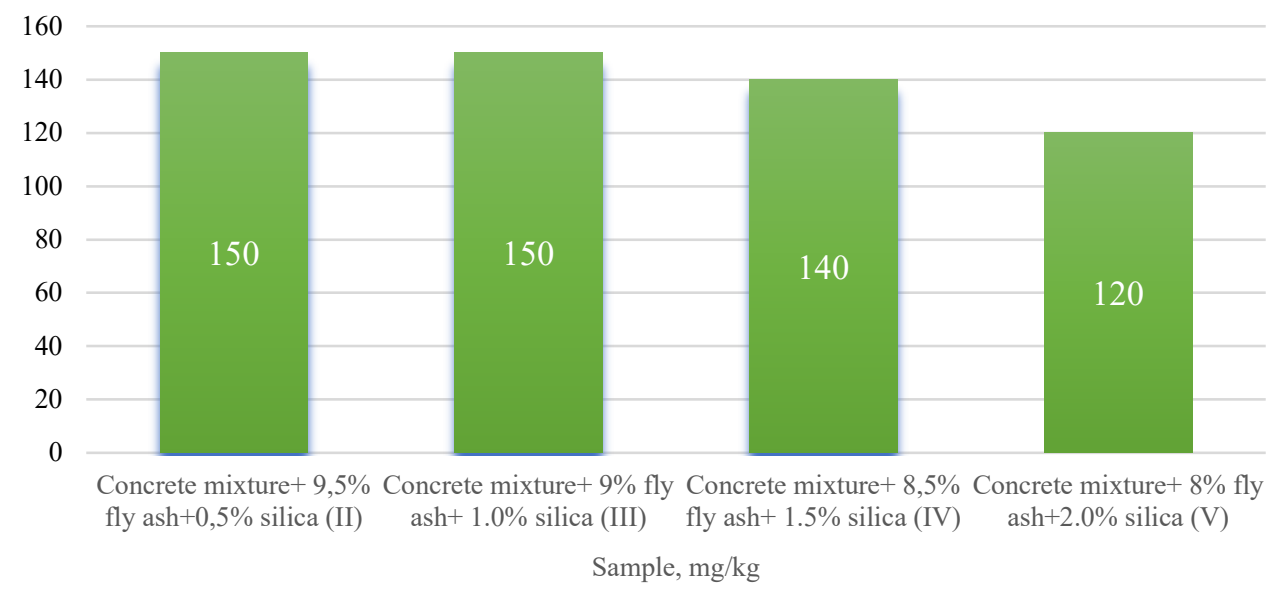


$\mathrm{Pb}$

(c)

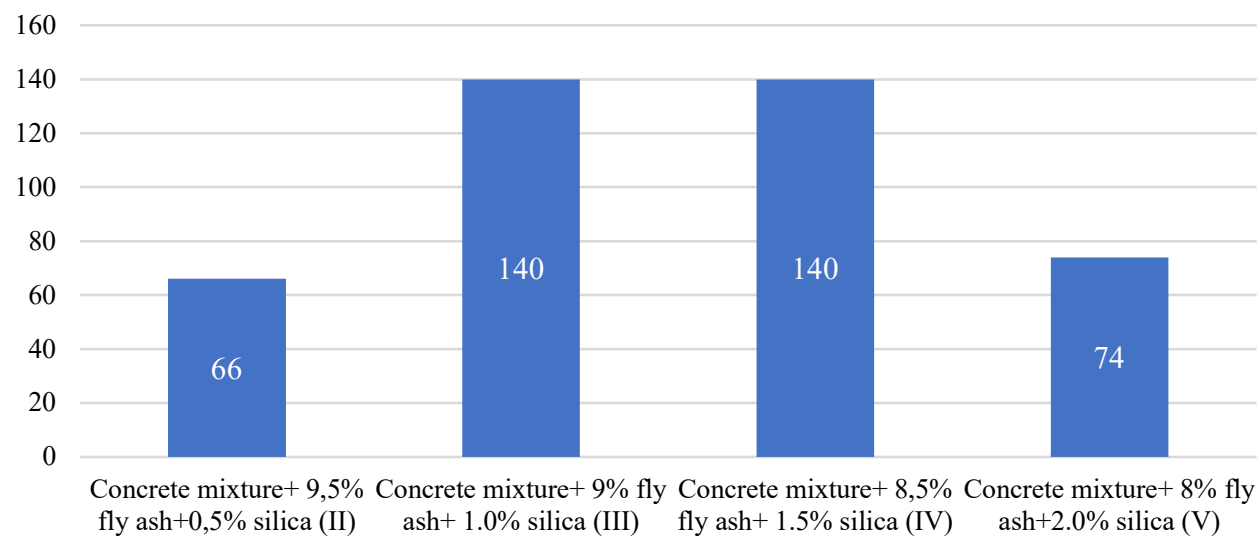

Sample, $\mathrm{mg} / \mathrm{kg}$

\section{Zn}

(d)

1200

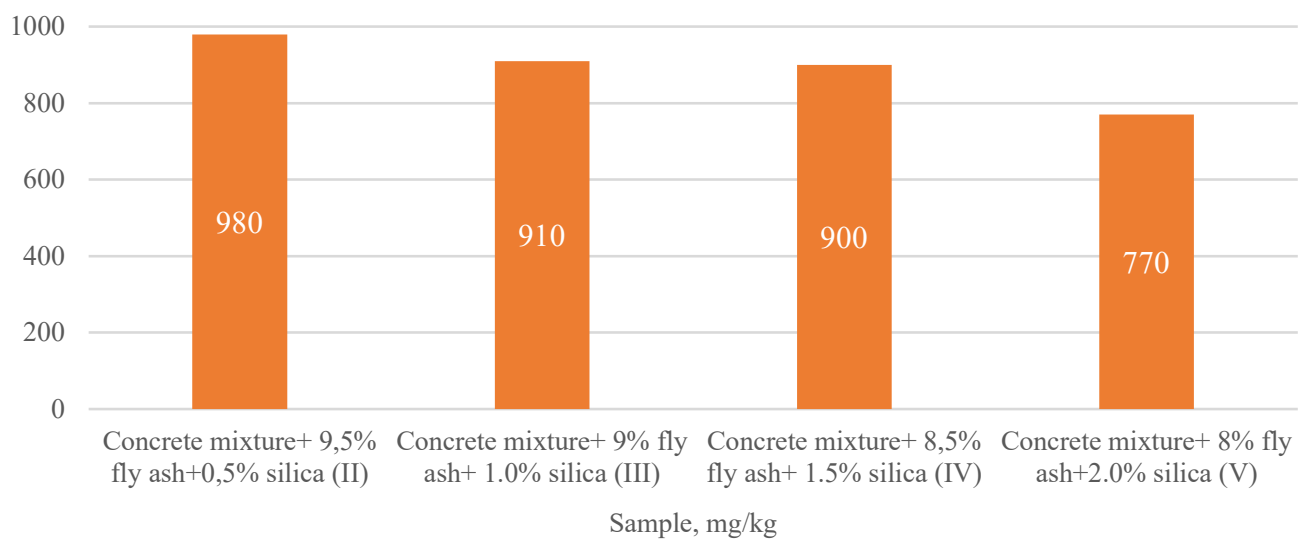

Fig. 2 Analysis of $\mathrm{Cd}(\mathrm{a}), \mathrm{Cu}(\mathrm{b}), \mathrm{Pb}(\mathrm{c}), \mathrm{Zn}$ (d) samples with concrete mixture, fly ash and silica nanocomposites

In this study, seven different samples were tested; four samples with various additions of silica, MSWI fly ash and concrete mixture; one with MSWI fly ash and concrete mixture; another only concrete mixture, and the last sample was with MSWI fly ash and silica. The main aim of this was to examine the possibility and effectiveness of silica nanocomposites on stabilizing heavy metals in MSWI fly ash.

Fig. 2 shows that concentration of $\mathrm{Cd}, \mathrm{Cu}, \mathrm{Pb}$, and $\mathrm{Zn}$ are decreased in the leaching solution of stabilized samples in comparison with original MSWI fly ash. The most sustainable and 
acceptable sample result is $\mathrm{V}(\mathrm{d})$ (concrete mixture $+8 \%$ fly ash $+2.0 \%$ silica nanocomposites) from four samples. In comparison with other $\mathrm{II}^{\mathrm{nd}}, \mathrm{III}^{\mathrm{rd}}$, and $\mathrm{IV}^{\text {th }}$ samples, where the composition (concrete mixture $+8 \%$ fly ash $+2.0 \%$ silica nanocomposites) of $\mathrm{w}(\mathrm{Cd})=9.8 \mathrm{mg} / \mathrm{kg}, \mathrm{w}(\mathrm{Cu})=120 \mathrm{mg} / \mathrm{kg}, \mathrm{w}(\mathrm{Pb})=74 \mathrm{mg} / \mathrm{kg}$ and $\mathrm{w}(\mathrm{Zn})=770$. The trend proves that the larger the amount of nanocomposite gives the higher the stabilization of metals in the sample. Mechanism introducing heavy metals incorporation and phase converting into the concrete mixture, MSWI fly ash, and silica nanocomposites as an additive.

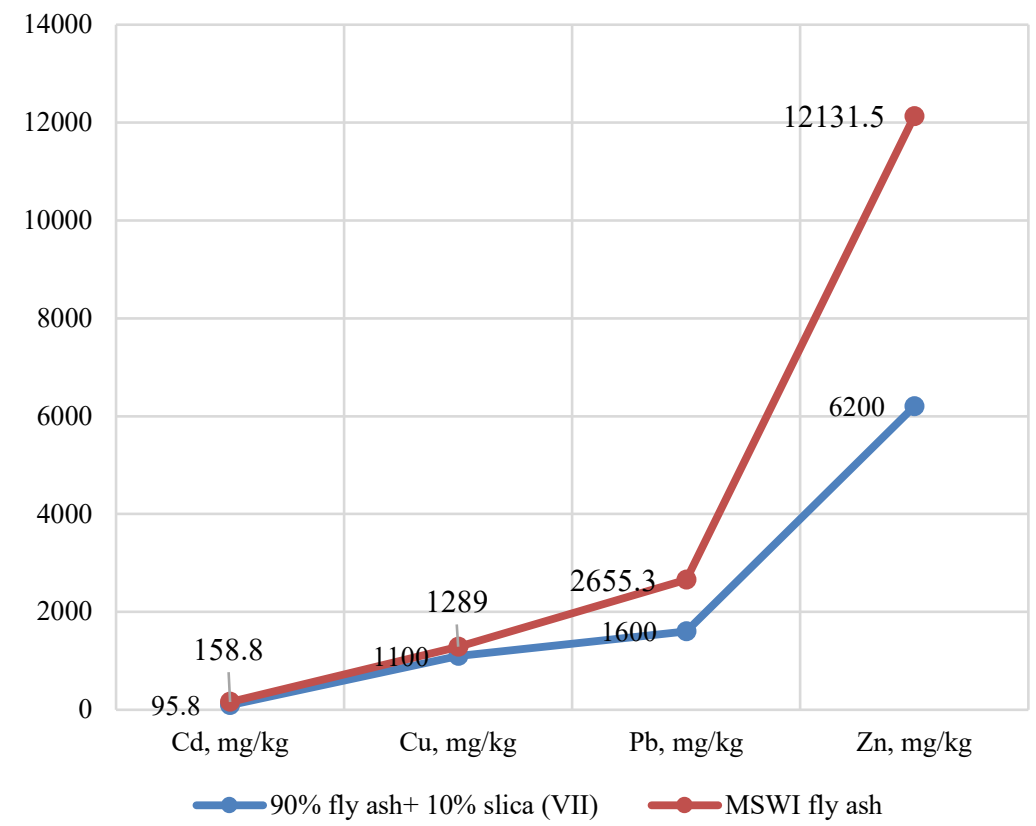

Fig. 3 Heavy metals behaviour in MSWI fly ash and MSWI fly ash+ silica nanocomposites.

Fig. 3 shows the concentration of $\mathrm{Zn}, \mathrm{Pb}, \mathrm{Cd}$, and $\mathrm{Cu}$ in leaching solution reduced respectively. It was already mentioned that silica nanocomposites that play a critical role in $\mathrm{Zn}, \mathrm{Pb}, \mathrm{Cd}, \mathrm{Cu}$ stabilization procedure. This highlights that stabilization with $10 \%$ of silica nanocomposites have effectiveness and decrease value significantly. For almost twice $\mathrm{Zn}$ has changed after the stabilization process, but $\mathrm{Pb}, \mathrm{Cu}$ and $\mathrm{Cd}$ decreased for $5931.5 \mathrm{mg} / \mathrm{kg}$, $1055.3 \mathrm{mg} / \mathrm{kg}$, and $189 \mathrm{mg} / \mathrm{kg}$, respectively. However, VII sample with $90 \%$ fly ash $+10 \%$ had a high concentration for all heavy metals and this is not comparable for use as concrete use application.

Fig. 4 shows heavy metals behaviour of $\mathrm{Cd}, \mathrm{Cu}, \mathrm{Pb}$ and, $\mathrm{Zn}$ of I, VI, V and all samples have a different composition. During the leaching analysis, the concrete mixture Weber S 100 concentration of heavy metals is acceptable norms. As an experimental way, it was used as additive material only MSWI fly ash in $10 \%$ and it was observed that value of all heavy metals had a comparable with sample concrete mixture with fly ash and silica nanocomposites, but values varied $\mathrm{Cd}$ in the I (concrete mixture with $10 \%$ fly ash) sample higher for $2.9 \mathrm{mg} / \mathrm{kg}, \mathrm{Cu}$ for $60 \mathrm{mg} / \mathrm{kg}, \mathrm{Zn}$ for $230 \mathrm{mg} / \mathrm{kg}$. However, concrete mixture with $10 \%$ fly ash had lower values of $\mathrm{Pb}$, which means silica fume not efficient for $\mathrm{Pb}$. 
1200

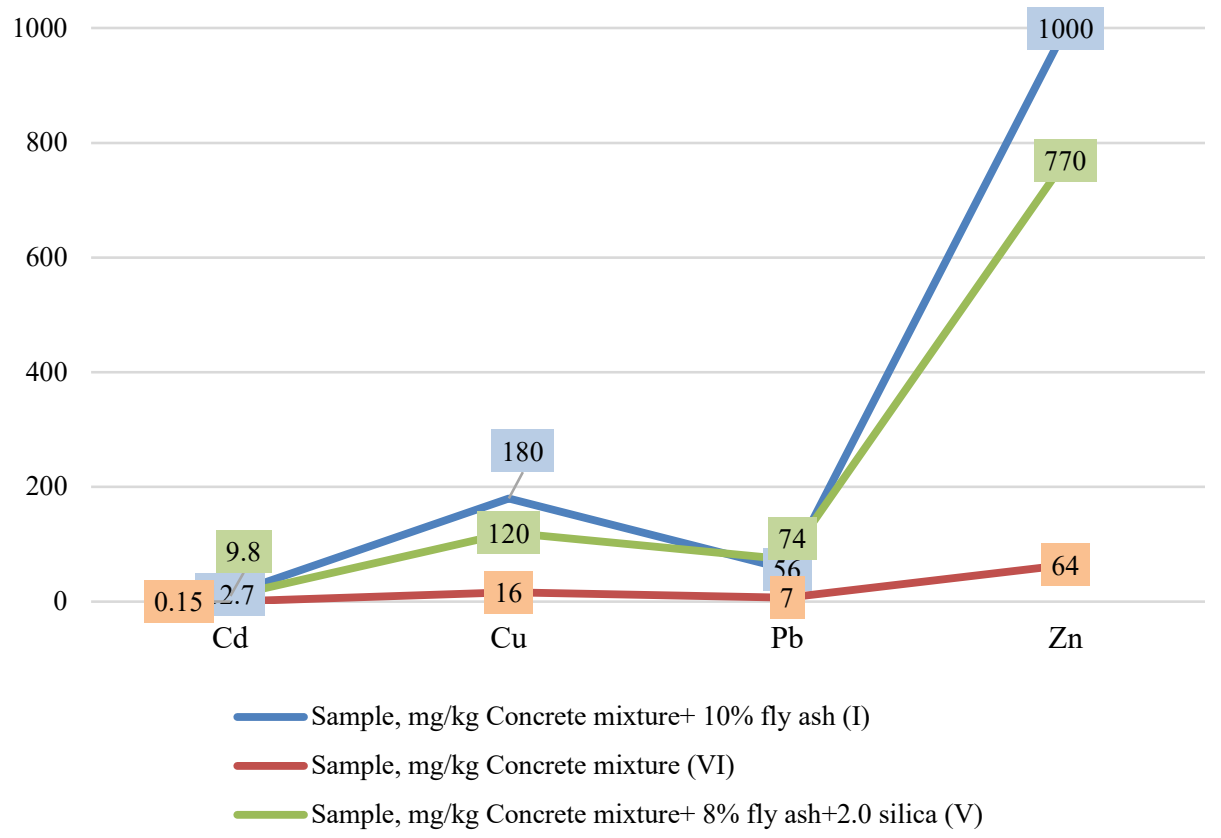

Fig. 4 Heavy metals concentration of I, V, and VI samples.

The most sustainable method is sample $\mathrm{V}$ that had the most efficient results and may have possibilities to use in the concrete mixture, but it is using concrete mixture without any additive have a great leaching result.

The analytical part of this research includes the Strength, Weakness, Opportunities, and Threats (SWOT) analysis for assessing internal and external factors of proposed technique: stabilization of heavy metals in MSWI fly ash with silica nanocomposites in the concrete.

The SWOT analysis was used to develop a strategic plan for introducing new capabilities in MSWI fly ash management. The purposes are recognizing negative and positive sides. The SWOT analysis examines the potential use of fly ash in terms of economic, environmental, and social sustainability [12].

Presently, MSWI fly ash is difficult to use due to the inconsistent composition of heavy metals, salts, organic matter, etc. It is also known that the use of ash is growing rapidly in different countries every year, as there are huge studies of the properties of MSWI fly ash for the purpose of use in building materials.

The main objective of SWOT for this research: assess of stabilization of heavy metals in MSWI fly ash technology and examination of a product as a concrete mixture with $8 \%$ of MSWI fly ash and $2 \%$ silica nanocomposites and decide how to move forward.

Table 4 shows the summary of the SWOT analysis assessment of potential stabilization heavy metals in the concrete with Silica nanocomposites. According to SWOT analysis were determined as positive and negative sides as well to assist in making strategic plans and decisions. 
TABle 4. Determination of HeAvy Metals: CADMium, CopPer, LeAD AND ZinC IN SEVEN SAMPLES

\begin{tabular}{|c|c|}
\hline \multicolumn{2}{|l|}{ Internal factors } \\
\hline Strengths & Weaknesses \\
\hline Cost reduction & The need to use a large amount of water \\
\hline $\begin{array}{l}\text { Makes it possible to solve the problem of aggregate } \\
\text { replacement }\end{array}$ & Slows the growth of concrete strength at an early age \\
\hline $\begin{array}{l}\text { Contributes to the disposal of waste from Incineration } \\
\text { Plant }\end{array}$ & Lack of knowledge in this area \\
\hline Significant energy saving & Risk with new concrete mix recipes \\
\hline \multicolumn{2}{|l|}{ External factors } \\
\hline Opportunities & Threats \\
\hline $\begin{array}{l}\text { Environmental protection: Efficient use of natural } \\
\text { resources, reducing the number of landfills }\end{array}$ & Cause health problems due to toxicity and radioactivity \\
\hline Change status from being a waste to become a product & No support from the municipality and public \\
\hline Economic benefits of commercializing this technology & Not sufficiently effective stabilization of heavy metals \\
\hline To make concrete more durable & Problems from practical use \\
\hline
\end{tabular}

Strengths of realization of this project: a mixture with MSWI fly ash and silica nanocomposites can significantly reduce material consumption which significantly will reduce cost. The new technology of concrete provides opportunities to solve the problem of aggregate replacement. Thus, this technology promotes the disposal of waste from an Incineration Plant which is considered as hazardous waste. In addition, one of the benefits of using MSWI fly ash is that it can increase the durability of hardened concrete and replacement can reduce the number of reactive aluminates available [13]. Concrete production currently requires a lot of energy, thus concrete with MSWI fly ash and silica nanocomposites can reduce $\mathrm{CO}_{2}$ emissions which is vital under the requirements. Furthermore, concrete mixture will accelerate the pozzolanic reaction during the hardening of concrete and improve packing density.

Weaknesses. The main barriers to the introduction of concrete with MSWI fly ash and silica nanocomposites for wider use because to a large extent the risk of developing new technology that is not subject to long-term field trials. Varnishes may be largely due to the risks involved in using new technology that is not subject to lengthy field trials. The companies are reluctant to take the risk with new concrete mix recipes, even if it reduces carbon dioxide emissions. However, there are some examples of Green companies that implement different mix recipes for concrete production. Also, during the preparation of concrete mortars, the new technology requires more water than ordinary concrete that puts pressure on water consumption. Due to a lack of awareness of this technology in public that could lead to some difficulties in explanation.

Furthermore, the production of concrete with fly ash and silica nanocomposites requires using a lot of water which in the future may affect increased pressure on water resources and possible expectations to experience water stress in the regions. The leaching test for MSWI fly ash would be obligatory due to the high content of heavy metals, salts, etc., which may complicate the situation for using this alternative.

Opportunities. Usually, MSWI fly ash going to landfill for hazardous waste, and thanks to this technology it could be used for concrete production, thereby reducing the number of landfills or completely not using them. MSWI fly ash composition is well studied that gives 
chances of using for concrete production. In terms of sustainability, the alternative solution gives potentials for Environmental protection and the efficient use of natural resources. Moreover, this technology also can the status of MSWI fly ash from being a waste become a product which is really important and could get the Economic benefits of commercializing this technology.

Threats. Technique that has not been sufficiently tested could give chances of no support from the government and public in total. In the beginning stages, the realization of the project requires a lot of research, and economic conditions can affect financial viability. A combination of MSWI fly ash and silica nanocomposites with concrete could stabilize heavy metals but not that efficiently, and exploitation of this could lead to health issues due to toxicity and radioactivity. Also, exist some issues from practical use of MSWI fly ash and silica nanocomposites due to the low bulk density that leading to dust formation, high osmotic activity and weak adsorption.

\section{CONCLUSION}

1. Continuously increasing the generation of waste creates serious problems for the waste management system. Incineration is one of the effective ways of reducing waste at $90 \%$.

2. The composition of MSWI fly ash is harmful to human health and the environment due to hazardous content as heavy metals, salts, and organic matter.

3. Concrete solidifying MSWI fly ash is a very useful treatment method for fly ash in a natural environment for safer disposal and if altering an appropriate storage condition;

4. The experimental research plan was divided into three parts: Investigation of Municipal Solid Waste Fly Ash; Stabilization of heavy metals; SWOT analysis.

5. Nanocomposites are becoming very popular due to the huge advantages gained from it. Silica materials are a promising technique to stabilize MSWI fly ash. The use of a new method for stabilizing heavy metals is considered an effective in reduction the leaching of toxic heavy metals.

6. The content of toxic heavy metals in the fly ash directly depends on those found in municipal solid waste incinerated.

7. In this study, seven different samples were tested; four samples with various additions of silica, one with MSWI fly ash and concrete mixture; one with concrete mixture, and the last sample was with MSWI fly ash and silica nanocomposites.

8. The best result of stabilization was sample V (concrete mixture $+8 \%$ fly ash $+2.0 \%$ silica nanocomposites) from rest four samples with silica nanocomposites. In a comparison of concentration heavy metals of original MSWI fly ash and MSWI fly ash + silica nanocomposites (VII), VII has efficient results and has good possibilities for stabilization $\mathrm{Cd}, \mathrm{Cu}, \mathrm{Pb}$, and $\mathrm{Zn}$.

9. The results give impetus to further research in the field of secondary raw materials for concrete mixtures. 


\section{REFERENCES}

[1] Joseph A. M., et al. The use of municipal solidwaste incineration ash in various building materials: A Belgian point of view. Materials 2018:11(1):141. https://doi.org/10.3390/ma11010141

[2] Lam C. H. K., et al. Use of incineration MSW ash: A review. Sustainability 2010:2(7):1943-1968. https://doi.org/10.3390/su2071943

[3] Martins I., Esteves A., Forth J. P. Chemical characterization and leaching of treated fly ash from a MSWI plant. Portugal SB07: Sustainable construction, materials and practices: challenge of the industry for the new millennium. Amsterdam: IOS Press, 2007:(1-2):935-942.

[4] Sawell S. E., et al. An international perspective on the characterisation and management of residues from MSW incinerators. Biomass and Bioenergy 1195:9(1-5):377-386. https://doi.org/10.1016/0961-9534(95)00105-0

[5] Xinghua H., Shujing Z., Hwang J.-Y. Physical and chemical properties of MSWI fly ash. Characterization of Minerals, Metals, and Materials 2016:451-459. https://doi.org/10.1007/978-3-319-48210-1 56

[6] Karantonis J. L. The Hazards of Fly Ash. UNSW Canberra ADFA Journal Of Undergraduate Engineering Research 2012:4(1).

[7] Sun X., et al. A Review on the Management of Municipal Solid Waste Fly Ash in American. Procedia Environmental Sciences 2016:31:535-540. https://doi.org/10.1016/j.proenv.2016.02.079

[8] Camargo P. H. C., Satyanarayana K. G., Wypych F. Nanocomposites: Synthesis, structure, properties and new application opportunities. Materials Research 2009:12(1):1-39. https://doi.org/10.1590/S1516-14392009000100002

[9] Pundinaitė-Barsteigienė M., et al. MSWI Bottom Ash Utilization In Concrete Mixe. Civil and transport engineering, aviation technologies 2017:9(5):524-530. (in Lithuanian) https://doi.org/10.3846/mla.2017.1081

[10] Kalogirou E., et al. Fly Ash Characteristics From Waste-to-Energy Facilities and Processes For Ash Stabilization. Environmental Science 2010:10.

[11] Tang Q., et al. Solidification/Stabilization of Fly Ash from a Municipal Solid Waste Incineration Facility Using Portland Cement. Advances in Materials Science and Engineering, Special Issue: Earth Materials and Environmental Applications 2016 2016:7101243. https://doi.org/10.1155/2016/7101243

[12] Aich A. Ghosh S. K. Application of SWOT Analysis for the Selection of Technology for Processing and Disposal of MSW. Procedia Environmental Sciences 2016:35:209-228. https://doi.org/10.1016/j.proenv.2016.07.083

[13] Pierre-Claude M. Sustainability of Concrete (Modern Concrete Technologies). Boca Raton: CRC Press, 2017:53(9). 